\title{
A numerical study of cell merger over Cuba - Part I: implementation of the ARPS/MM5 models
}

\author{
D. Pozo ${ }^{1}$, I. Borrajero ${ }^{2}$, J. C. Marín ${ }^{1}$, and G. B. Raga ${ }^{1}$ \\ ${ }^{1}$ Centro de ciencias de la Atmósfera, UNAM, México, Ciudad Universitaria, México, DF, 04510, México \\ ${ }^{2}$ Instituto de Meteorología de Cuba, Loma de Casablanca, Regla, C. Habana, Cuba
}

Received: 4 November 2005 - Revised: 19 September 2006 - Accepted: 20 September 2006 - Published: 21 November 2006

\begin{abstract}
On 21 July 2001 a number of severe storms developed over the region of Camaguey, Cuba, which were observed by radar. A numerical simulation was performed in order to realistically reproduce the development of the storms observed that day. The mesoscale model MM5 was used to determine the initial, boundary and update conditions for the storm-scale simulation with the model ARPS. Changes to the source code of ARPS were made in order to assimilate the output from the MM5 as input data and a new land-use file with a 1-km horizontal resolution for the Cuban territory was created.
\end{abstract}

A case representing the merger between cells at different stages of development was correctly reproduced by the simulation and is in good agreement with radar observations. The state of development of each cell, the time when the merger occurred, starting from the formation of clouds, the propagation motion of the cells and the increase in precipitation, due to the growth of the area after the merger, were correctly reproduced. Simulated clouds matched the main characteristics of the observed radar echoes, though in some cases, reflectivity tops and horizontal areas were overestimated. Maximum reflectivity values and the heights where these maximum values were located were in good agreement with radar data, particularly when the model reflectivity was calculated without including the snow. The MM5/ARPS configuration introduced in this study, improved sensibly the ability to simulate convective systems, thereby enhancing the local forecasting of convection in the region.

Keywords. Meteorology and atmospheric dynamics (Convective processes; Mesoscale meteorology; Precipitation)

Correspondence to: D. Pozo

(dianarpl@yahoo.com)

\section{Introduction}

On 21 July 2001 numerous severe storms developed over the region of Camagüey, Cuba, which were detected by radar. Cloud merger was observed in some of these storms, including one that later produced a hailstorm over the area. Cloud merger has been described with the use of numerical cloud models, together with observational studies (Simpson and Woodley, 1971; Houze and Cheng, 1977; Lopez, 1978; Westcott, 1994), focusing on finding pre-storm ambient conditions which favor the occurrence of a merger, in order to obtain qualitatively and quantitatively the aspects that may improve its prediction. However, most of those numerical studies on cloud merger have been initialized with horizontally homogeneous environments and some of them under conditions of weak wind and wind shear or even calm conditions (Wilkins et al., 1976; Orville et al., 1980; Turpeinen and Yau, 1981; Tao and Simpson, 1984; Kogan and Shapiro 1996), which simplify the simulations.

This paper presents results from a simulation obtained with the aid of two numerical models: the Advanced Regional Prediction System (ARPS) and the Fifth-Generation NCAR/Penn State Mesoscale Model (MM5). The environmental 3-D fields needed as input data to run ARPS were obtained from a mesoscale simulation using the MM5. The aim was to reproduce the development of the storms observed on 21 July 2001 in the most realistic way possible, avoiding the inclusion of initial perturbations. A case representing the merger between cells at different stages of development was reproduced, in agreement with that detected by radar. The physical mechanisms responsible for the occurrence of this cloud merger are studied in the second part of this work.

Sections 2 and 3 present the meteorological situation observed on 21 July 2001 and the radar description, respectively. A description of ARPS, detailing the modifications introduced in this study, the initialization procedure and the configuration used in MM5 are presented in Sect. 4. Results

Published by Copernicus GmbH on behalf of the European Geosciences Union. 


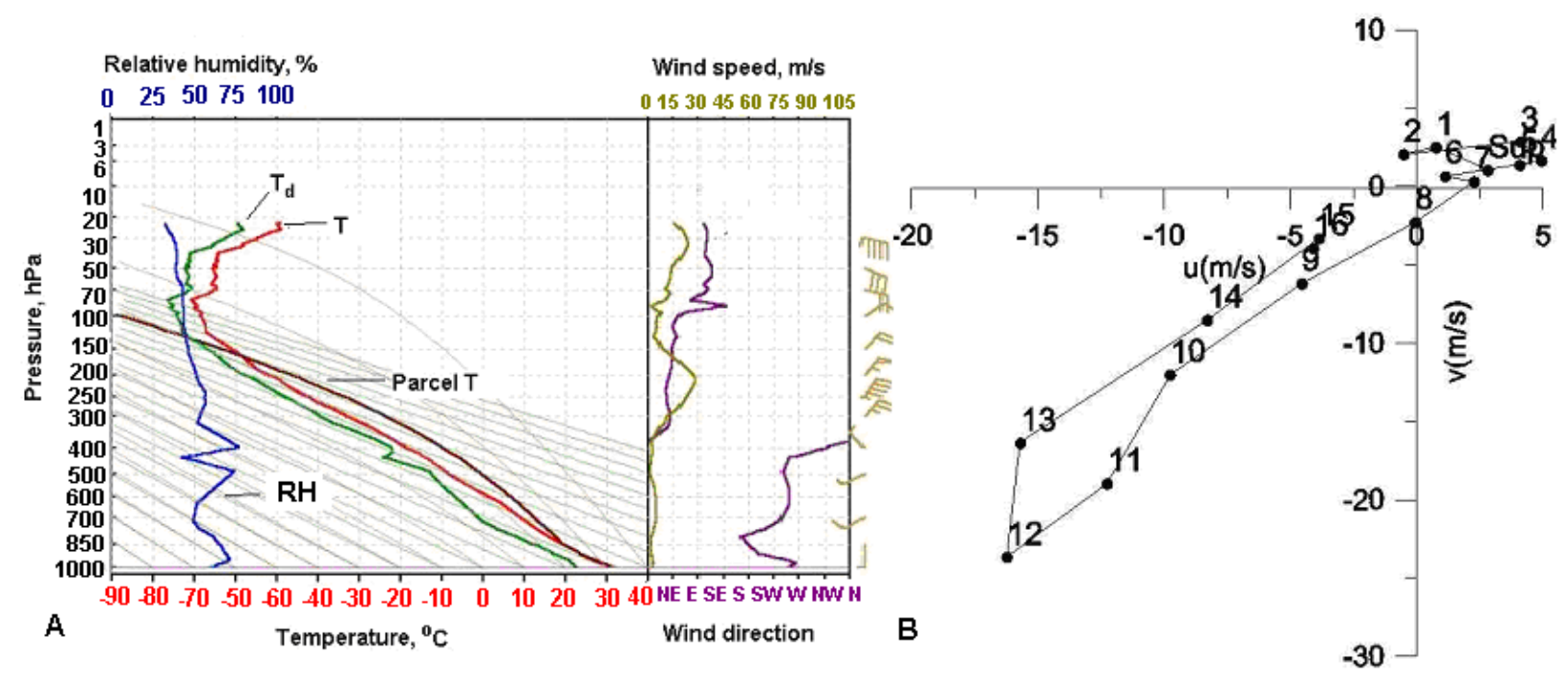

Fig. 1. (A) 18:00 GMT sounding of 21 July 2001, measured at the meteorological surface station of Camaguey, (B) representation of the hodograph measured at that hour.

and discussion from the simulation are presented in Sect. 5 . Finally, Sect. 6 presents the conclusions.

\section{Meteorological situation of 21 July 2001}

The meteorological situation over the region on that day was characterized by the influence of a weak high pressure with surface winds from the southwest. The maximum and minimum temperatures were $34.9^{\circ} \mathrm{C}$ and $19.4^{\circ} \mathrm{C}$, respectively, as measured at Nuevitas (in the province of Camagüey), where a hailstorm was later reported.

The 18:00 GMT sounding from the Camagüey station $\left(21^{\circ} 25^{\prime} \mathrm{N}, 77^{\circ} 10^{\prime} \mathrm{W}\right)$ (Fig. 1a) exhibits a deep moist layer, a well-mixed sub-cloud layer and high convective available potential energy (CAPE), of $3351 \mathrm{~J} / \mathrm{kg}$. The low level wind is relatively weak, with a variable direction from $\mathrm{W}-\mathrm{SW}$ at low levels, but turning preferentially clockwise up to $10 \mathrm{~km}$ at the base of a jet from the NE that extends to $16 \mathrm{~km}$ (Fig. 1b). The wind profile presents three different layers in the troposphere: a low level shear layer from the surface to $7 \mathrm{~km}$, a higher level shear layer with wind speeds increasing with height from 7 to $12 \mathrm{~km}$, and a layer with wind speed decreasing with height from 12 to $16 \mathrm{~km}$.

\section{Radar description}

The radar system used on this study was an MRL_5 model (made in the Soviet Union), with a wavelength of $10.14 \mathrm{~cm}$, pulse power of $510 \mathrm{KW}$, a beam width of $1.5 \mathrm{deg}$ and pulse length of 1 and $2 \mathrm{~ms}$. It was located $2 \mathrm{~km}$ northeast of the center of the modelling domain. The radar and sounding data employed in this study were obtained during a field experiment. Several studies have been conducted on the experimental site in the Camaguey region (Koloskov et al., 1996; Alfonso et al., 1998; Martínez and Gori, 1999).

The parameters selected for comparison with results from the simulation were the height of the reflectivity top $(H)$, the maximum reflectivity $(R \max )$, the height where the maximum reflectivity is located (Hrmax) and the horizontal extent (Area) of the precipitation.

\section{Model configuration and initialization}

\subsection{External 3-D meteorological field}

An operationally implemented MM5 configuration was used for this study. Its output was used as input to ARPS to supply the external 3-D data and the mesoscale information needed to simulate the severe storms over Cuba. Changes in the source code for ARPS were introduced to accept the output of MM5. Three nested domains of $90 \times 90 \mathrm{~km}, 30 \times 30 \mathrm{~km}$ and $10 \times 10 \mathrm{~km}$ of horizontal resolution were selected in the MM5 simulation, using the results of the innermost domain to include it as background. This simulation lasted $18 \mathrm{~h}$ from 21 July 2001 at 00:00 GMT and boundary conditions were updated every $6 \mathrm{~h}$ from the AVN model.

The external 3-D meteorological field used as input to ARPS in the present paper was made by the ADAS (ARPS's Data Analysis System) (Brewster, 1996). For analysis of state variables, ADAS uses a successive-correction scheme (Bratseth, 1986) with a telescoping correlation parameter that allows for the use of a variety of data sets with varying spatial resolution. Four analysis passes are performed, 
Table 1. Maximum differences (Difmax) observed at the surface between the background and the analysis when the surface stations data were included.

\begin{tabular}{lr}
\hline \multicolumn{1}{c}{ Variables } & \multicolumn{1}{c}{ Difmax } \\
\hline Pressure $(\mathrm{mb})$ & 0.8 \\
Temperature $\left({ }^{\circ} \mathrm{C}\right)$ & 1.8 \\
Mixing ratio $(\mathrm{kg} / \mathrm{kg})$ & $1.00 \mathrm{E}-006$ \\
u-component $(\mathrm{m} / \mathrm{s})$ & 1.4 \\
v-component $(\mathrm{m} / \mathrm{s})$ & 0.6 \\
\hline
\end{tabular}

Table 2. Maximum differences (Difmax) observed between the background and the analysis at heights (h) lower than $4 \mathrm{~km}$ and higher than $9 \mathrm{~km}$ when the sounding was included.

\begin{tabular}{lrr}
\hline \multicolumn{1}{c}{ Variables } & $\begin{array}{c}\text { Difmax } \\
(0<\mathrm{h}<4 \mathrm{~km})\end{array}$ & \multicolumn{1}{c}{$\begin{array}{c}\text { Difmax } \\
(\mathrm{h}>9 \mathrm{~km})\end{array}$} \\
\hline Pressure $(\mathrm{mb})$ & 0.3 & $6.00 \mathrm{E}-002$ \\
Temperature $\left({ }^{\circ} \mathrm{C}\right)$ & 0.5 & 0.05 \\
Mixing ratio $(\mathrm{kg} / \mathrm{kg})$ & $3.00 \mathrm{E}-007$ & $6.00 \mathrm{E}-007$ \\
u-component $(\mathrm{m} / \mathrm{s})$ & 1 & 1 \\
v-component $(\mathrm{m} / \mathrm{s})$ & 0.2 & 0.06 \\
\hline
\end{tabular}

using increasingly smaller spatial correlation distances (300, 120,80 and $60 \mathrm{~km}$ ), with a corresponding vertical parameter of $500 \mathrm{~m}$. The 18:00 GMT sounding from the Camagüey station and data from 29 local surface meteorological stations over the selected area were included, using as background the MM5 output.

Low-resolution simulations did not represent correctly the surface temperature of the Cuban island as the sea surface temperature because of its narrow extent. An improvement in this sense was obtained when the local surface meteorological stations data were included. Table 1 shows the maximum differences observed in several variables in the background field with and without the inclusion of the surface stations. A maximum difference of $1.8^{\circ} \mathrm{C}$ in the surface temperature is seen.

Another problem related to the background simulation is that it did not reproduce accurately the magnitude and direction of the sea breeze, due to the coarse representation of the coastline, together with the subestimation of the surface temperature. When the wind surface data from the stations were included, important variations in magnitude and direction were observed (Table 1), and the winds became more perpendicular along the coasts.

The mean temperature and wind variations were observed below an altitude of $4 \mathrm{~km}$ when the sounding was included (Table 2). On the other hand, the humidity was larger in the background than in the sounding above $8 \mathrm{~km}$. This difference in the moisture profile was also observed in the AVN

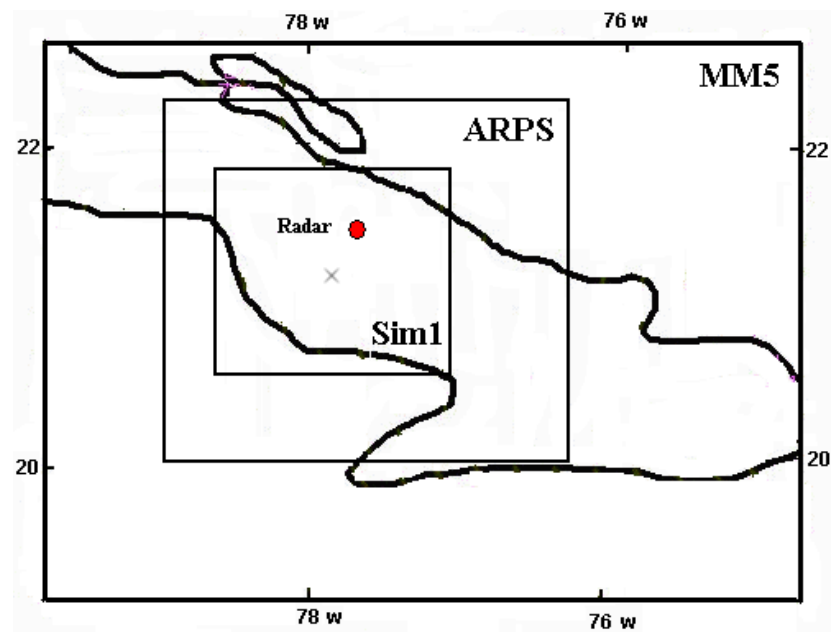

Fig. 2. Mother domains used in Sim1. MM5's highest resolution domain (10 km of horizontal resolution) which supplied the 3-D external data to the intermediate simulation made with ARPS, with a 3-km horizontal resolution, which provided initial and boundary external data to the internal domain Sim1. The point represents the localization of the radar. The cross represents the center of the domain in Sim1.

field which was used as an initialization in the MM5 simulation. After the assimilation of the sounding data, no new convergence zones appeared in the boundaries of its radius of influence. In summary, after the assimilation of all the data, the convergence field in the regions where the storms formed increased up to $20 \%$.

\subsection{ARPS parameterizations and configuration}

The numerical model ARPS was used and detailed information can be found in Xue et al. (1995, 2000, 2001, and 2003). A second order momentum advection scheme was used, as well as a sub-grid turbulence parameterization of the order of 1.5 , which involves the solution of an additional forecast equation for the turbulent kinetic energy. The microphysics parameterization scheme of Lin et al. (1983) for mixed phase processes was selected.

A simulation with ARPS, with a 3 and $0.5 \mathrm{~km}$ horizontal and vertical resolution, respectively, was initiated with the external 3-D field from MM5. Lateral boundary conditions were updated from MM5 outputs every half an hour. The simulation was initiated at 18:00 GMT and was run for $6 \mathrm{~h}$. Results from this intermediate simulation with ARPS supplied the initial and external boundary conditions data (every half an hour) to the current simulation (hereafter named Sim1). Sim 1 was run for $4 \mathrm{~h}$ with a $1.5-\mathrm{km}$ resolution in the horizontal and $0.5 \mathrm{~km}$ in the vertical direction. The center of the domain was situated at the site of the Camagüey upper air station. Figure 2 shows the domains used for each model. 

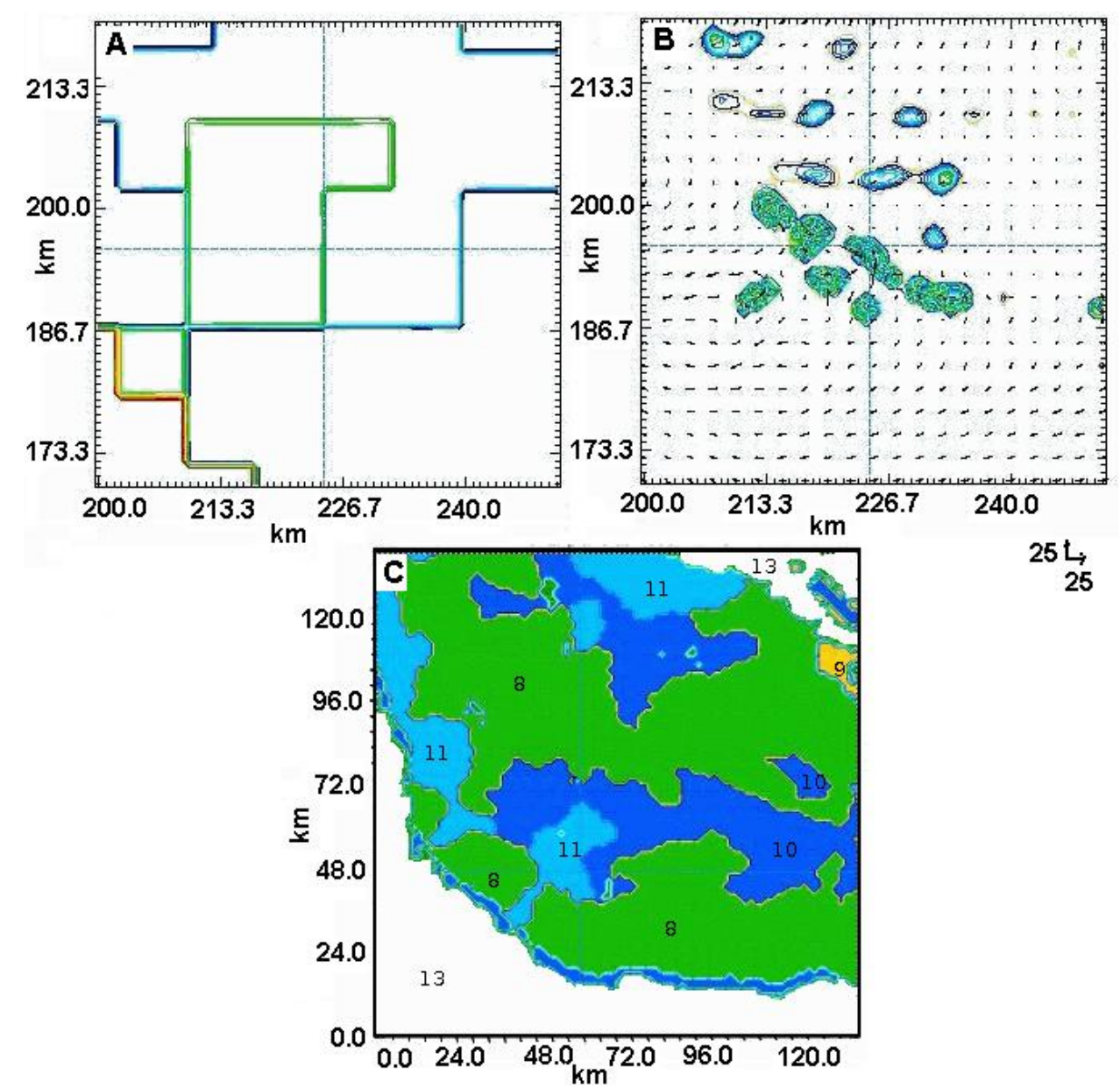

25

Fig. 3. Land-use representation for the zone of interest in the province of Camaguey (corresponding to domain Sim1): (A) land-use with a 10-km resolution; (B) simulation using the land-use of $10 \mathrm{~km}$ where unrealistic clouds appeared; (C) new land-use representation at a 1-km horizontal resolution according to ARPS: 8 - Clay loam, 9 - Sandy clay, 10 - Silty clay, 11 -Clay, 13 - Water.

\subsection{Topography and land use}

The selected domains in Fig. 2 are located between two irregular coastlines. In the afternoon hours, the sea breeze from both coasts generated zones of convergence, which favored the development of convection in the territory, in the absence of larger scale meteorological phenomena. The correct simulation of the breezes depended on a good representation of the coastline and the sea/land temperature difference.

In a simulation using the land use with a $10-\mathrm{km}$ of resolution (highest resolution available in the model), several clouds also developed in the boundaries of the different land use types (Figs. 3A, B). As a result, the ARPS model was modified to allow the assimilation of a new land-use file with $1 \mathrm{~km}$ of resolution. The new land-use with a 1-km resolution for the province of Camagüey is shown in Fig. 3C. When the new land-use file was used, clouds formed at realistic locations, in agreement with observations.

A sensitivity study was made where two simulations were performed with a terrain resolution of $10 \mathrm{~km}, 1 \mathrm{~km}$ and us- ing the same land-use resolution of $1 \mathrm{~km}$. Results showed that clouds developed in the same places in both simulations, since the highest elevation inside the inner domain was lower than the vertical resolution used, and is located several kilometers away from where the clouds formed. Thus, the role of the terrain to trigger convection in the inner domain was null, since it was almost flat in the region. However, in the outer domains there are zones with higher elevations that could generate orographic clouds. Both land-use and terrain, $1 \mathrm{~km}$ in resolution, were used in the simulation (Sim1).

\section{Results and discussion}

\subsection{Comments on the merger process}

Merger does not have a clear and established definition, as discussed by Wescott $(1984,1994)$, and since its first observational documentation (Byers and Braham, 1949) the term merger has been used in a wide range of situations. In 

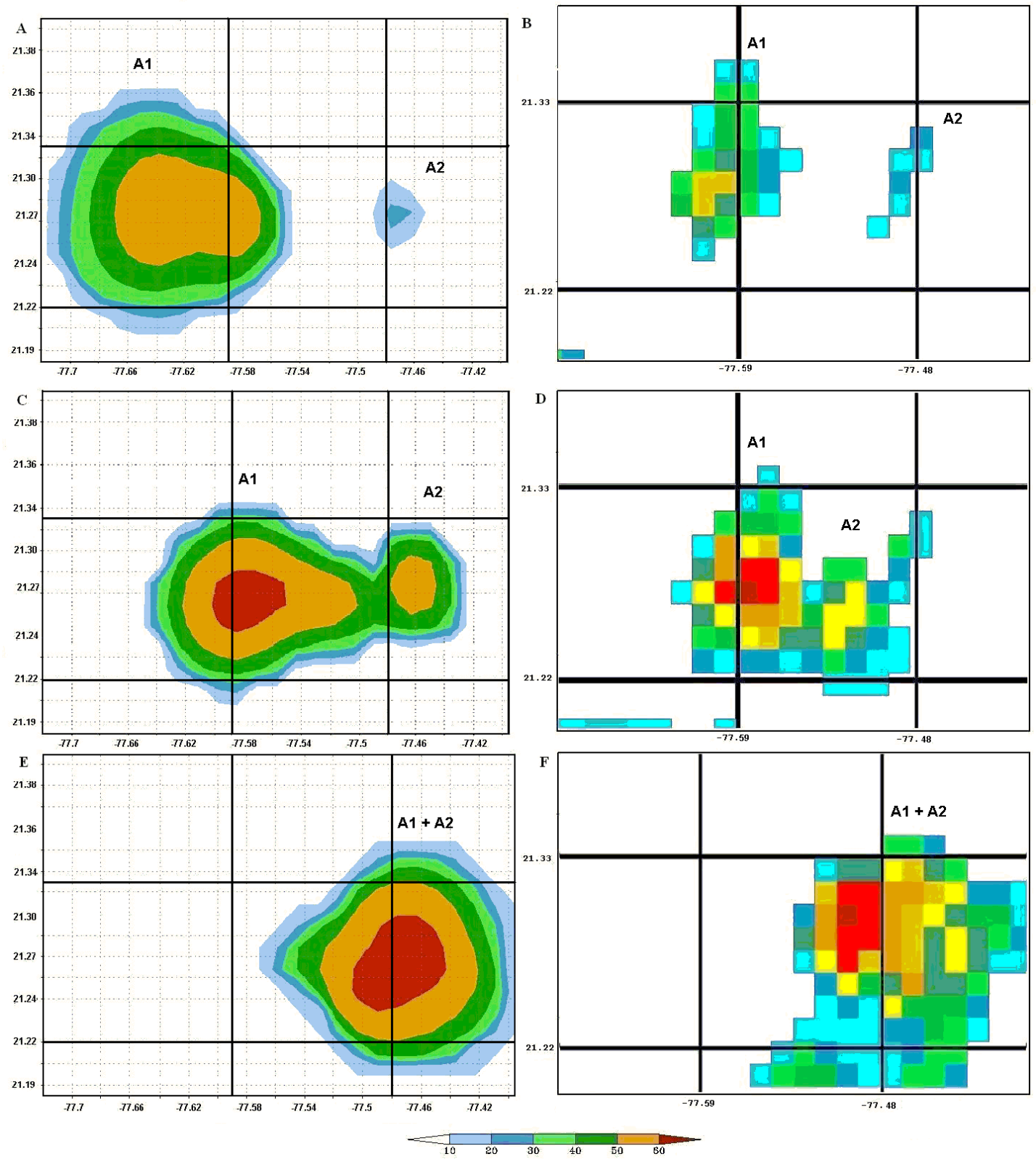

Fig. 4. Temporal evolution of the merger cells A1+A2 for 21 July 2001. (A, C, E): calculated reflectivity at $h=3 \mathrm{~km}$ at 9600,10800 and $12000 \mathrm{~s}$. Shaded areas beginning at $10 \mathrm{dBz}$ in intervals of $10 \mathrm{dBz}$. (B, D, F): corresponding radar images at 21:45, 22:05 and 22:25 GMT, respectively. Graphics from simulation correspond to a section of the whole domain.

observational studies, using conventional radar, merger has been described in terms of the reflectivity cores (Dennis et al., 1970; Lemon, 1976; Lopez, 1978; Cunning et al., 1982).

In numerical modeling studies, merger has been usually described either in terms of maximum updrafts or rainwater isopleths forming a single core (Turpeinen, 1982; Tao and Simpson, 1984; 1989; Kogan and Shapiro, 1996). In the current study, merger is defined by the joining of maximum updrafts and ranwater isolines in the analysis of the numerical simulation results. On the other hand, the joining of observed reflectivity cores of at least $20 \mathrm{dBz}$ will be taken as the occurrence of merger when the radar data is analyzed.

\subsection{Comparison between Sim1 and radar data}

In real life, as well as in the simulation, more than one storm developed in the region of study. Two cases of cloud merger were observed in Sim1: one between cells at different stages of development, and another between cells with approximately the same state of development. We present here the 
Table 3. Parameters from simulated clouds in Sim1 (9600s of simulation) and radar data at 21:45 GMT. $H$ : reflectivity top height $(q r+q h+q s), H^{*}$ : reflectivity top height $(q r+q h), R \max$ : maximum reflectivity value, Hrmax: height at maximum reflectivity value and reflectivity area.

\begin{tabular}{llllllllll}
\hline & \multicolumn{3}{c}{ Sim1 } & \multicolumn{4}{c}{ Radar } \\
\hline Clouds & $\begin{array}{l}H \\
(\mathrm{~km})\end{array}$ & $\begin{array}{l}H^{*} \\
(\mathrm{~km})\end{array}$ & $\begin{array}{l}\text { Rmax } \\
(\mathrm{dBz})\end{array}$ & $\begin{array}{l}\text { Hrmax } \\
(\mathrm{km})\end{array}$ & $\begin{array}{l}\text { Area } \\
\left(\mathrm{km}^{2}\right)\end{array}$ & $\begin{array}{l}H \\
(\mathrm{~km})\end{array}$ & $\begin{array}{l}\text { Rmax } \\
(\mathrm{dBz})\end{array}$ & $\begin{array}{l}\text { Hrmax } \\
(\mathrm{km})\end{array}$ & $\begin{array}{l}\text { Area } \\
\left(\mathrm{km}^{2}\right)\end{array}$ \\
\hline A1 & 14.5 & 11.5 & 59 & $6-7$ & 145 & $10-11$ & 61 & $7-8$ & 63 \\
A2 & 4.2 & 4.2 & 50 & $3-4$ & 6 & $4-5$ & 48 & $3-4$ & 13.2 \\
\hline
\end{tabular}
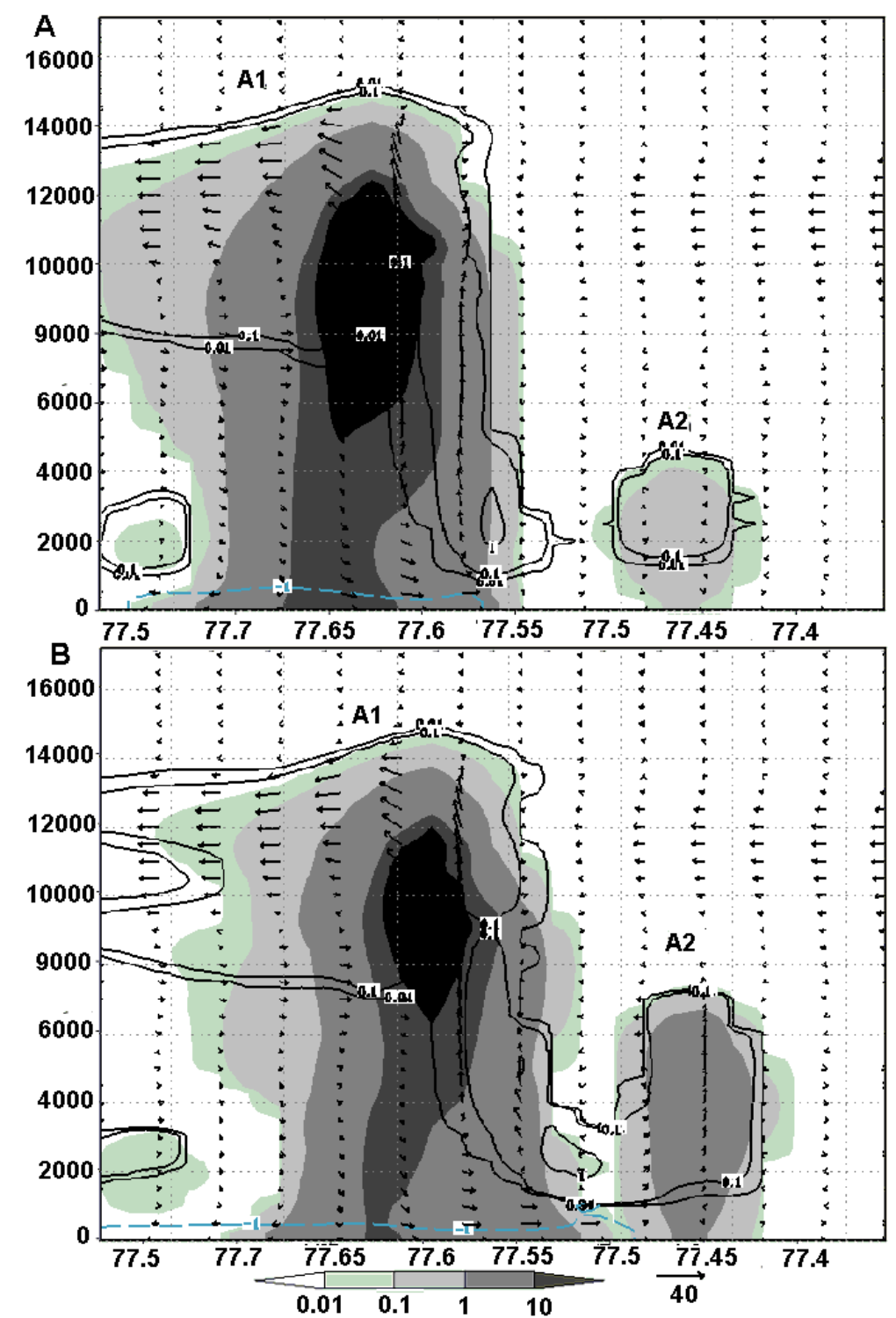

Fig. 5. Vertical cross section in Sim 1 . The shaded area represents $q r+q h+q s$, solid lines $q c+q i$, arrows represent wind velocity. (A) $9600 \mathrm{~s}$ of simulation. (B) $10200 \mathrm{~s}$ of simulation. The dashed blue line represents the cold pool of A1. 
Table 4. Parameters from simulated clouds in Sim1 (10800s of simulation) and radar data at 22:05 GMT. $H$ : reflectivity top height $(q r+q h+q s), H *$ : reflectivity top height $(q r+q h), R \max$ : maximum reflectivity value, Hrmax: height at maximum reflectivity value and reflectivity area.

\begin{tabular}{llllllllll}
\hline \multicolumn{1}{c}{ Sim1 } & \multicolumn{3}{c}{ Radar } \\
\hline Clouds & $\begin{array}{l}H \\
(\mathrm{~km})\end{array}$ & $\begin{array}{l}H^{*} \\
(\mathrm{~km})\end{array}$ & $\begin{array}{l}\text { Rmax } \\
(\mathrm{dBz})\end{array}$ & $\begin{array}{l}\text { Hrmax } \\
(\mathrm{km})\end{array}$ & $\begin{array}{l}\text { Area } \\
\left(\mathrm{km}^{2}\right)\end{array}$ & $\begin{array}{l}H \\
(\mathrm{~km})\end{array}$ & $\begin{array}{l}\text { Rmax } \\
(\mathrm{dBz})\end{array}$ & $\begin{array}{l}\text { Hrmax } \\
(\mathrm{km})\end{array}$ & $\begin{array}{l}\text { Area } \\
\left(\mathrm{km}^{2}\right)\end{array}$ \\
\hline A1 & 11.2 & 10.2 & 61.7 & $4-5$ & 123 & $9-10$ & 63 & $3-4$ & 74.8 \\
$\mathrm{~A} 2$ & 13.5 & 11.5 & 51 & $6-7$ & 48.4 & $9-10$ & 52 & $6-7$ & 61.6 \\
\hline
\end{tabular}

results of the former case and refer to Pozo (2004) for further discussion on the latter. The comparison between results of Sim1 and radar data shows that the state of development of each cloud, the time at which the merger took place, starting from the clouds formation; the direction of motion of the storms and the increase in precipitation due to the increment of the area after merger, were correctly reproduced.

The cloud merger was observed at 22:05 GMT in radar data, while in Sim1 it occurred at 21:00 GMT, corresponding with $10800 \mathrm{~s}$ of simulation. Figure 4 shows this process three times, where radar images starting at 21:45 GMT and horizontal cross sections from Sim1, starting at $9600 \mathrm{~s}$, are compared. The comparison begins $25 \mathrm{~min}$ before the cloud merger takes place in Sim1 and in the radar data at 5-min intervals. Figures from Sim 1 and radar images have a horizontal resolution of 1.5 and $1.3 \mathrm{~km}$, respectively. Reflectivity values above $10 \mathrm{dBz}$ are shown in the figures, which is the minimum value observed in radar images. The $2500-3500-\mathrm{m}$ layer for radar images and the horizontal plane at $\mathrm{z}=3000 \mathrm{~m}$ from Sim 1 were chosen to better illustrate the merger process, which occurred well away from domain boundaries.

\subsubsection{Cloud merger between cells at different stages of de- velopment}

At $9600 \mathrm{~s}$ of simulation (Fig. 4A), two cells, A1 and A2, are developing. Cell A1 is in its development stage, while A2 is still in its formation stage. This is also observed in Fig. 4B, at 21:45 GMT for the radar image. The value of $H$ for A2 (Table 3) was similar to the value observed in the radar image at 21:45 GMT, while $H$ was overestimated for A1. Rmax and Hrmax for both cells were in good agreement with values observed in the radar images. Reflectivity areas present the largest differences, with A1 in Sim1 greatly overestimating the observed value and A2 underestimating it. Qualitatively, A1 was wider than A2 and the simulated parameters represent adequately the stage of development of each cloud.

Figure 5A shows the vertical cross section of interacting clouds A1 and A2 at $9600 \mathrm{~s}$ of simulation, through the maximum updrafts of the cells. The shaded area represents the sum of the rainwater, snow and hail mixing ratios $(q r+q h+q s)$, solid lines represent cloud water and ice wa- ter mixing ratio $(q c+q i)$. Arrows represent the wind velocity vector in the $\mathrm{X}-\mathrm{Z}$ plane. Cell A1 extends vertically up to $14.5 \mathrm{~km}$ and horizontally for $20 \mathrm{~km}$. It has a maximum updraft of $35 \mathrm{~m} / \mathrm{s}$, a maximum rainwater content ( $q r$ ) of $15 \mathrm{~g} / \mathrm{kg}$ and values of hail content $(q h)$ higher than $10 \mathrm{~g} / \mathrm{kg}$. Cell A2 appears to the right of A1 with a weak updraft and complete absence of downdraft, maximum values of $q r$ of $4.47 \mathrm{~g} / \mathrm{kg}$ and cloud top height (defined as the height where the sum of the hydrometeors is greater than $0.01 \mathrm{~g} / \mathrm{kg}$ ) below $4.5 \mathrm{~km}$. Hail and ice water contents are not present, and its width does not exceed $4.5 \mathrm{~km}$. Both cells appear joined by a cloud bridge in Fig. 5B (10200 s). The observation of a cloud bridge before the cloud merger has been reported in many studies and has been associated with the convergence of cold outflows from downdrafts of interacting clouds (Simpson et al., 1980; Cunning and DeMaria, 1986; Wescott and Kennedy, 1989). Tao and Simpson $(1984,1989)$ also observed a cloud bridge preceding the cloud merger in studies with numerical simulations. The cloud bridge could not be seen in radar images because of the low reflectivity values and the coarse resolution of the radar.

Ten minutes later (10800 s of simulation), cell A1 is in an advanced stage (Fig. 6A), with high values of precipitation at the surface and significant downdrafts. A2 initiates its development stage with updrafts larger than $30 \mathrm{~m} / \mathrm{s}$. Table 4 shows that $H$ and Hrmax have decreased in $\mathrm{A} 1$ and Rmax increased for both Sim 1 and the radar data. On the other hand, an increase in all parameters in A2 is observed in both the simulation and radar data (Figs. 4C, D). All parameters simulated were in good agreement with values observed in radar data at 22:05 GMT, though $H$ and the area for A2 were somewhat over and underestimated, respectively.

At $10800 \mathrm{~s}$ (Fig. 6A) values of rainwater larger than $1 \mathrm{~g} / \mathrm{kg}$ have begun to merge at mid-levels. Updraft cores have not joined yet at higher levels, leaving both cloud tops clearly separated. Part of the downdraft from A1 is incorporated into the updraft in $\mathrm{A} 2$, strengthening the convergence that favors its development. It is obvious that the two cells are at different stages in their development. Cell A1 is starting to decay at the time of the merger, but after it happens, the new cloud rapidly develops, reaching up to $14 \mathrm{~km}$ (Fig. 6B). 

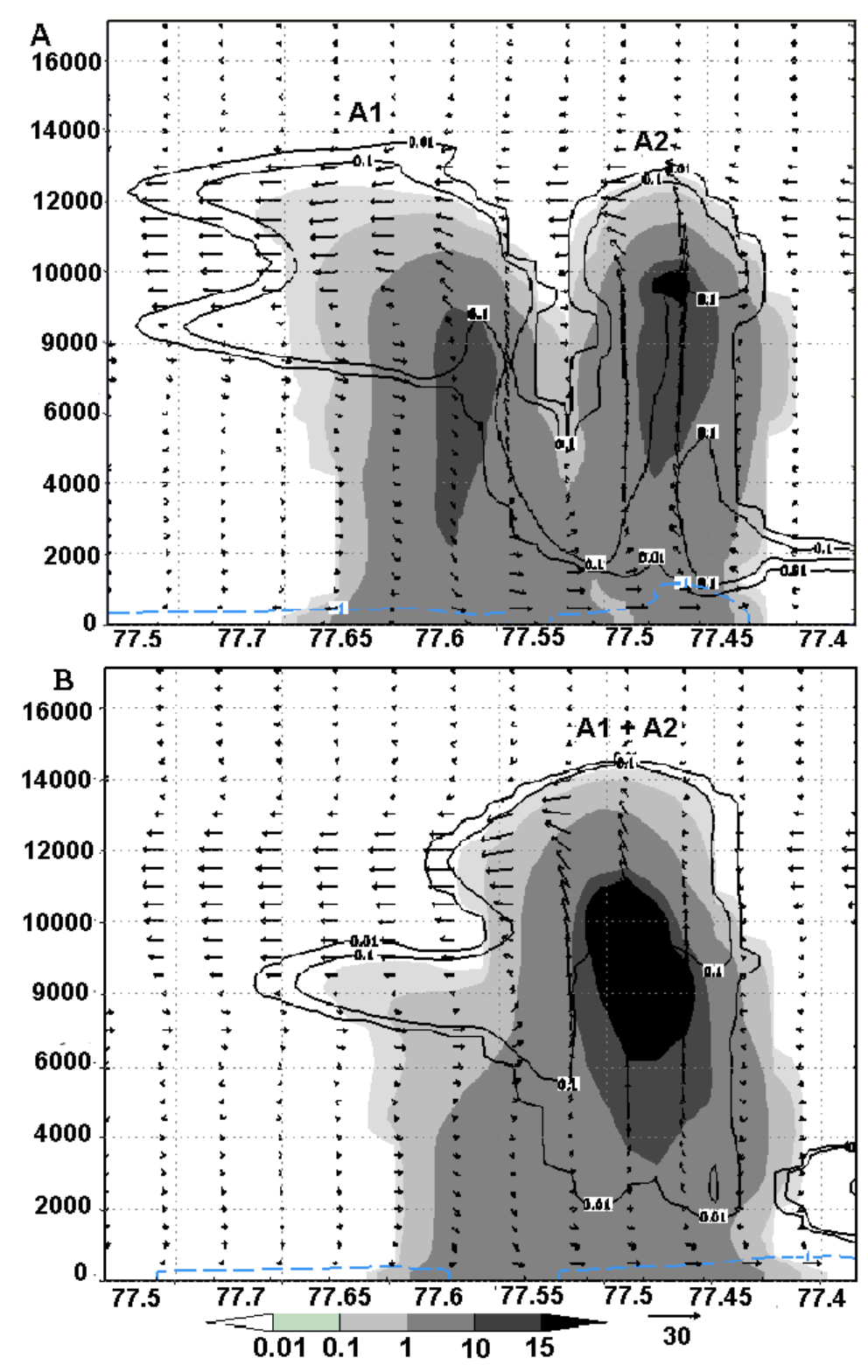

Fig. 6. Vertical cross section in Sim1. The shaded area represents $q r+q h+q s$, solid lines $q c+q i$, arrows represent wind velocity. (A) $10800 \mathrm{~s}$ of simulation. (B) $11400 \mathrm{~s}$ of simulation. The dashed blue line represents the cold pool of A1+A2.

A comparison between the first level of Sim 1 and the surface stations data was made at $10800 \mathrm{~s}$ to analyze to what extent the simulation was in agreement with the measured surface data (it was the only observation data available during Sim1). Figure 7 shows the temperature (Fig. 7A) and the wind components (Figs. 7B, C) at the surface from the model and the station data at $10800 \mathrm{~s}$ of simulation. The figure indicates a model cool bias of about $-0.4^{\circ} \mathrm{C}$ when compared with the surface data. The wind components in the model are in good agreement with observations, except at the scs station, where the $v$-component of the wind differs by $1.5 \mathrm{~m} / \mathrm{s}$ from the observed value. Despite the good agreement in the com- parison, it should be noted that it is made between the first level of the model $(100 \mathrm{~m})$ and surface stations data, thereby introducing an uncertainty.

At $11400 \mathrm{~s}$ of simulation (Fig. 6B), a single updraft dominating the merged cloud $\mathrm{A} 1+\mathrm{A} 2$ is seen, co-located with a maximum reflectivity core, showing an increase in the maximum updraft from the previous time. This confirms the occurrence of cloud merger by the coalescence of interacting updrafts at middle and higher levels coincident with a maximum reflectivity core (Kogan and Shapiro, 1996; Stalker and Knupp, 2003). Byers and Braham (1949) and Bringi et al. (1997) in observational studies and Kogan and Shapiro 


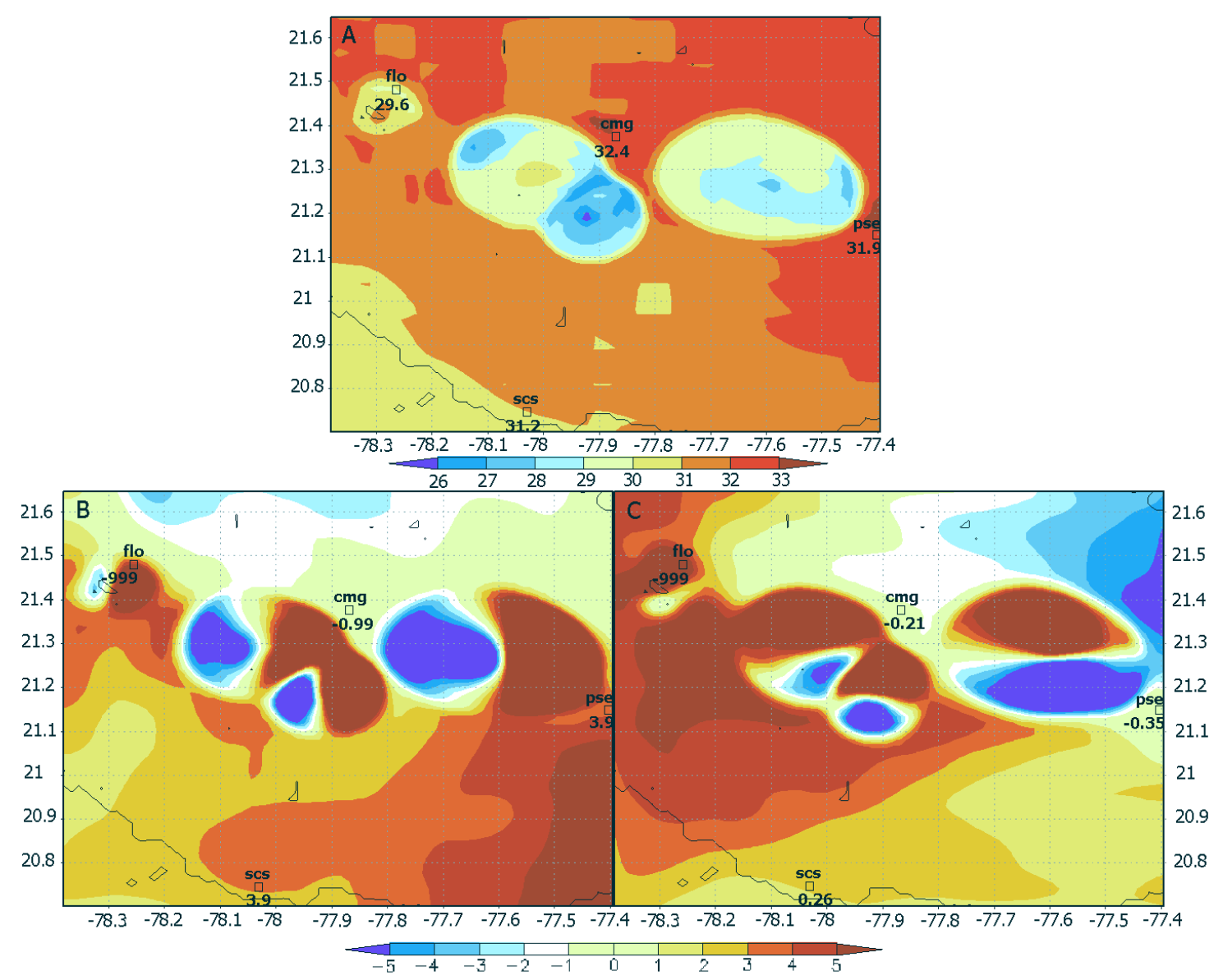

Fig. 7. Horizontal cross section at the surface at $10800 \mathrm{~s}$. (A): Temperature $\left({ }^{\circ} \mathrm{C}\right)$. $(\mathbf{B}): u$-component $(\mathrm{m} / \mathrm{s})$. $(\mathbf{C}): v$-component $(\mathrm{m} / \mathrm{s})$. The simulation values are drawn in shaded contours. Squares represent the station locations, with their station ID and observation values. A -999 value represents a missing data.

Table 5. Parameters from simulated clouds in Sim1 (11400s of simulation) and radar data at 22:15 GMT. $H$ : reflectivity top height $(q r+q h+q s), H *$ : reflectivity top height $(q r+q h)$, Rmax: maximum reflectivity value, Hrmax: height at maximum reflectivity value and reflectivity area.

\begin{tabular}{llllllllll}
\hline & \multicolumn{3}{c}{ Sim1 } & \multicolumn{4}{c}{ Radar } \\
\hline Clouds & $\begin{array}{l}H \\
(\mathrm{~km})\end{array}$ & $\begin{array}{l}H^{*} \\
(\mathrm{~km})\end{array}$ & $\begin{array}{l}\text { Rmax } \\
(\mathrm{dBz})\end{array}$ & $\begin{array}{l}\text { Hrmax } \\
(\mathrm{km})\end{array}$ & $\begin{array}{l}\text { Area } \\
\left(\mathrm{km}^{2}\right)\end{array}$ & $\begin{array}{l}H \\
(\mathrm{~km})\end{array}$ & $\begin{array}{l}\text { Rmax } \\
(\mathrm{dBz})\end{array}$ & $\begin{array}{l}\text { Hrmax } \\
(\mathrm{km})\end{array}$ & $\begin{array}{l}\text { Area } \\
\left(\mathrm{km}^{2}\right)\end{array}$ \\
\hline A1+A2 & 14 & 11.5 & 66 & $6-7$ & 198 & $11-12$ & 70 & $5-6$ & 206 \\
\hline
\end{tabular}

(1996) and Stalker and Knupp (2003) in numerical studies considering rainwater isolines, have shown similar results. Downdrafts are dominant at low levels and a new cell appears to the right of $\mathrm{A} 2$ due to the convergence with the environmental wind (Fig. 6B). The new cell moved in a northeast direction, together with new developing cells. The formation and movement of new cells was in good agreement with radar observations.
Table 5 shows an increase in $H, R \max$ and the reflectivity area for merged clouds, both in Sim 1 and the radar data, with respect to the original cells when compared with the previous time. A similar evolution has been described by Lemon (1976), Houze and Cheng (1977), Wescott (1977) and Woodley et al. (1982). Hrmax, however, decreased in both cases after merger.

At 12000 s of simulation, simulated values were in good agreement with the corresponding values determined by the 
Table 6. Parameters from simulated clouds in Sim1 (12000s of simulation) and radar data at 22:25 GMT. H: reflectivity top height $(q r+q h+q s), H *$ : reflectivity top height $(q r+q h), R \max$ : maximum reflectivity value, Hrmax: height at maximum reflectivity value and reflectivity area.

\begin{tabular}{llllllllll}
\hline \multicolumn{1}{c}{ Sim1 } & \multicolumn{3}{c}{ Radar } \\
\hline Clouds & $\begin{array}{l}H \\
(\mathrm{~km})\end{array}$ & $\begin{array}{l}H^{*} \\
(\mathrm{~km})\end{array}$ & $\begin{array}{l}\text { Rmax } \\
(\mathrm{dBz})\end{array}$ & $\begin{array}{l}\text { Hrmax } \\
(\mathrm{km})\end{array}$ & $\begin{array}{l}\text { Area } \\
(\mathrm{km})^{2}\end{array}$ & $\begin{array}{l}H \\
(\mathrm{~km})\end{array}$ & $\begin{array}{l}\text { Rmax } \\
(\mathrm{dBz})\end{array}$ & $\begin{array}{l}\text { Hrmax } \\
(\mathrm{km})\end{array}$ & $\begin{array}{l}\text { Area } \\
\left(\mathrm{km}^{2}\right)\end{array}$ \\
\hline $\mathrm{A} 1+\mathrm{A} 2$ & 12 & 11.5 & 66 & $2-3$ & 193 & $11-12$ & 67 & $2-3$ & 167 \\
\hline
\end{tabular}

Table 7. Calculated mean square error of H, Rmax and Hrmax from Sim1 and radar error.

\begin{tabular}{cccc}
\hline & $\begin{array}{c}\mathrm{H} \\
(\mathrm{km})\end{array}$ & $\begin{array}{c}\mathrm{Rmax} \\
(\mathrm{dBz})\end{array}$ & $\begin{array}{c}\text { Hrmax } \\
(\mathrm{km})\end{array}$ \\
\hline $\begin{array}{c}\text { Root mean square } \\
\text { error for Sim1 } \\
\text { Radar error }\end{array}$ & 1.0 & 1.2 & 0.6 \\
\hline
\end{tabular}

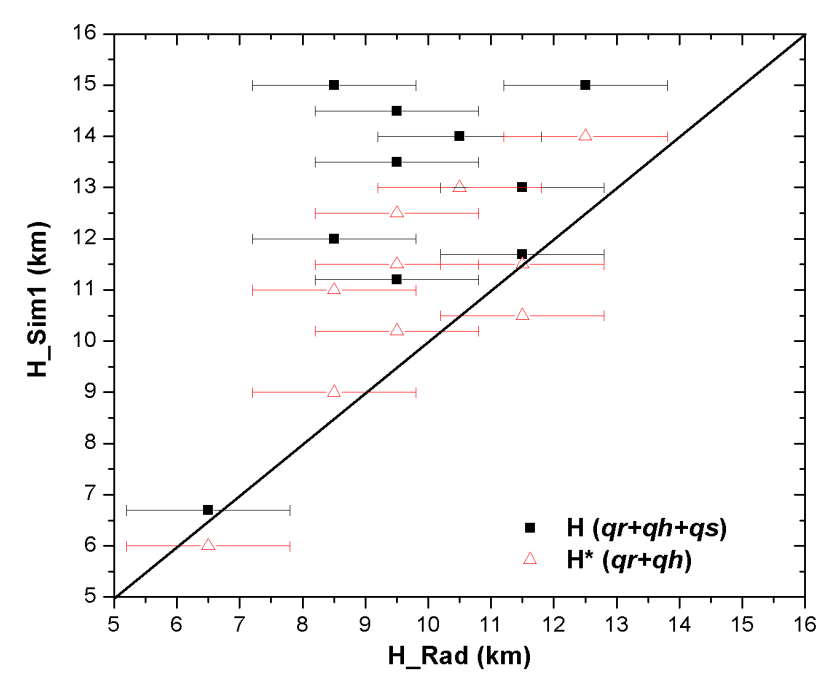

Fig. 8. Reflectivity top height from Sim1 vs. reflectivity top height from radar. Bar error represents the $1.3 \mathrm{~km}$ of radar error. The solid line corresponds to $1: 1$.

radar at 22:25 GMT (Table 6). Even though the area shows some difference with the observed value, this difference is close to the estimated error, as will be discussed below. Evidence of the occurrence of cloud merger at $12000 \mathrm{~s}$ of simulation and 22:25 GMT can also be appreciated in Figs. 4E, $\mathrm{F}$, where a clear single cloud $\mathrm{A} 1+\mathrm{A} 2$ is seen.

In general, in Fig. 4, it can be observed that cloud positions were in good agreement with the radar data during the simu- lation time. The main difference can be found at $10800 \mathrm{~s}$ for A2, which was located $6.5 \mathrm{~km}$ to the northwest.

Another case of merger simulated in Sim 1 between cells at almost the same stage of development was also analyzed and similar results to those presented here were obtained regarding the comparison with radar data. No strengthening of the system took place in this case after the merger, perhaps due to the advanced stage of development of the clouds.

\section{Error analysis}

Table 7 shows the root mean square error calculated for $H$, Rmax and Hrmax derived from the simulations and from radar observations. Errors calculated for these three parameters in Sim1 are within the range of error of radar measurements. The error in the reflectivity area measured by radar is $20 \%$, so its relative error was estimated. The comparison shows that $60 \%$ of the simulated cases exceeded the radar error.

Mean square errors calculated for maximum values like Rmax and Hrmax were smaller than for $H$ and the area derived from a radar with fairly coarse resolutions. The area is defined by a contour of minimum reflectivity values detected by radar and the probability of measuring them with a large error is higher than when measuring maximum values. Even though the area had the largest error, it behaved qualitatively as observed by radar. A reason for the differences may be related to the fact that a $10-\mathrm{cm}$ radar cannot distinguish dry snow, as that present near the top of the cloud. The simulated values of a reflectivity top included $q r, q h$ and $q s$, but when the reflectivity was recalculated, taking into account only $q r$ and $q h$, new reflectivity top values $\left(H^{*}\right)$ were obtained. Figure 8 shows the sensitivity of the height of the reflectivity top, and though some values of $\mathrm{H}^{*}$ are still overestimated, they are in closer agreement to radar observations than $H$ values determined from $q r, q h$ and $q s$.

\section{Conclusions}

The model ARPS was modified to assimilate the output from the MM5 model as input data and a new land-use file with 
1-km horizontal resolution for Cuba was incorporated, improving its ability to simulate convective systems in this area. The simulations utilized the output from MM5 as initial and boundary conditions, as well as upper air data and complementary surface data from the region. The ARPS simulation with this configuration reproduced successfully the general features of the behavior of the severe storms that occurred on 21 July 2001. The good agreement between simulated and observed cloud systems indicate that the improved configuration for ARPS/MM5 can be used in local forecasts of convective storms in the region.

An analysis of a case representing the merger between cells at different stages of development, which was correctly reproduced by the simulation and in good agreement when compared with radar observations, was presented. The state of development of each cell, the time when the merger occurred, starting from the clouds formation, the propagation motion of the cells and the increase in precipitation due to the growth of the area after the merger were correctly reproduced. Overall, simulated clouds matched the main characteristics of the observed radar echoes, though in some cases, reflectivity top and horizontal cell areas were overestimated. Maximum reflectivity values and the height where these maximum values were located were in good agreement with radar observations. The removal of the $q s$ field in the calculation of the height of the reflectivity top improved the agreement with radar observations, perhaps suggesting either that the snow was overestimated in the simulation or that the coarse radar resolution was unable to detect the snow present.

The physical processes responsible for the case representing the merger presented here are explored further in a companion paper, where idealized conditions of cell development are used.

Acknowledgements. The authors would like to thank both reviewers for their comments and suggestions which improved the quality of this paper. The authors also thanks the Oklahoma University for giving free access to ARPS model.

Topical Editor F. D'Andrea thanks K. Brewster and another referee for their help in evaluating this paper.

\section{References}

Alfonso, L., Martínez, D., and Pérez, C. A.: Numerical simulation of tropical convective clouds over Cuba using a one-dimensional and time-dependent cloud model, Atmospheric Research, 47-48, 343-354, 1998.

Bratseth, A. M.: Statistical interpolation by means of successive corrections. Tellus, 38A, 439-447, 1986.

Brewster, K.: Application of a Bratseth analysis scheme including Doppler radar data, Preprints, 15th Conference on Weather Analysis and Forecasting, Amer. Meteor. Soc., Norfolk, VA, 92-95, 1996.

Bringi, V. N., Knupp, K. R., Detwiler, A., Liu, L., and Black, R. A.: Evolution of a Florida Thunderstorm during the Convection and
Precipitation/Electrification Experiment: The case of 9 August 1991, Mon. Wea. Rev., 125, 2131-2160, 1997.

Byers, H. R. and Braham, R. R.: The Thunderstorm, U.S. Weather Bur., Washington D.C., 287, 1949.

Cunning, J. B. and DeMaria, M.: An investigation of development of cumulonimbus systems over South Florida, Part I: Boundary layer interactions, Mon. Wea. Rev., 114, 5-24, 1986.

Cunning, J. B., Holle, R. H., Gannon, P. T., and Watson, A. I.: Convective evolution and merger in the FACE experimental area: Mesoscale convection and boundary layer interactions. J. Appl. Meteor., 21, 953-977, 1982.

Dennis, A. S., Schock, C. A., and Koscielsky, A.: Characteristics of hailstorms of western South Dakota. J. Appl. Meteor., 9, 127$135,1970$.

Houze Jr., R. A. and Cheng, C.-P.: Radar characteristics of tropical convection observed during GATE: Mean properties and trends over the summer season, Mon. Wea. Rev., 105, 964-980, 1977.

Kogan, Y. L. and Shapiro, A.: The simulation of a convective cloud in a 3D model with explicit microphysics, Part II: Dynamical and microphysical aspects of cloud merger, J. Atmos. Sci., 53, 17, 2525-2545, 1996.

Koloskov, B., Zimin, B., Beliaev, V., Seregin, Y.,Chernikov, A., Petrov, V., Valdés, M., Martínez, D., Pérez, C., and Puente, G.: Results of Experiments on Convective Precipitation Enhancement in the Camagüey Experimental Area, Cuba. Jour. Appl. Meteor., 45, 9, 1524-1534, 1996.

Lemon, L. R.: The flanking line, a severe thunderstorm intensification source, J. Atmos. Sci., 33, 686-694, 1976.

Lin, Y. L., Farley, R. D., and Orville, H. D.: Bulk parameterization of the snow field in a cloud model, J. Clim. Appl. Meteor., 22, 1065-1092, 1983.

Lopez, R. E.: Internal structure and development processes of Cscale aggregates of cumulus clouds, Mon. Wea. Rev., 106, 1488 1494, 1978.

Martínez, D. and Gori, E. G.: Raindrop size distributions in convective clouds over Cuba. Atmos. Res., 52, 221-239, 1999.

Orville, H. D., Kuo, Y.-H., Farley, R. D., and Hwang, C. S.: Numerical simulation of cloud interactions, J. Rech. Atmos., 14, 499-516, 1980.

Pozo, D. R.: Simulación numérica de la formación y evolución de sistemas nubosos convectivos de mesoescala sobre Camagüey con ayuda de un modelo tridimensional, Ph. D. dissertation, Instituto de Meteorología. Cuba, 123, 2004.

Simpson, J. and Woodley, W. L.: Seeding cumulus in Florida, New 1970 results. Science, 172, 117-126, 1971.

Simpson, J., Westcott, N. E., Clerman R. J., and Pielke, R. A.: On cumulus mergers, Arch. Meteor. Geophys. Bioklim., 29A, 1-40, 1980.

Stalker, J. R. and Knupp, K. R.: Cell merger potential in multicell thunderstorms of weakly sheared environments: Cell separation distance versus planetary boundary layer depth, Mon. Wea. Rev., 131, 1678-1695, 2003.

Tao, W. K. and Simpson, J.: Cloud interactions and merging: Numerical simulations. J. Atmos. Sci., 41, 2901-2917, 1984.

Tao, W. K. and Simpson, J.: A further study of cumulus interactions and mergers: Three dimensional simulations with trajectory analyses, J. Atmos. Sci., 46, 2974-3004, 1989.

Turpeinen, O. and Yau, M. K.: Comparisons of results from a threedimensional cloud model with statistics of radar echoes on day 
261 of GATE, Mon. Wea. Rev., 109, 1495-1511, 1981.

Turpeinen, O.: Cloud interactions and merging on day 261 of GATE, Mon. Wea. Rev., 110, 1238-1254, 1982.

Wescott, N. E.: Radar characteristics of South Florida convective rainfall. Proceedings, Sixth Conference on Planned and Inadvertent Weather Modifications, Champaign-Urbana, I11, 10-13 October 1977, AMS, Boston, 190-191, 1977.

Wescott, N. E.: A historical perspective on cloud mergers. Bull. Amer. Meteor. Soc., 65, 219-226, 1984.

Westcott, N. E.: Merging of convective clouds: Cloud initiation, bridging, and subsequent growth. Mon. Wea. Rev., 122, 780$790,1994$.

Wescott, N. E. and Kennedy, P. C.: Cell development and merger in an Illinois thunderstorm observed by Doppler radar, J. Atmos. Sci., 46, 117-131, 1989.

Wilkins, E. M., Sasaki, Y. W., Gerber, G. E., and Chaplin, Jr., W. H.: Numerical simulation of lateral interactions between buoyant clouds. J. Atmos. Sci., 33, 1321-1329, 1976.

Woodley, W. L., Jill, L., Barnston, A., Simpson, J., Biondini, R., and Flueck, J.: Rainfall results of the Florida Area Cumulus Experiments, 1970-1976, J. Appl. Meteor., 21, 139-164, 1982.
Xue, M., Droegemeier, K. K., Wong, V., Shapiro A., and Brewster, K.: ARPS Version 4.0 User's Guide, Available from Center for Analysis and Prediction of Storms, University of Oklahoma, Norman OK 73072, 380, 1995.

Xue, M., Droegemeier, K. K., and Wong, V.: The Advanced Regional Prediction System (ARPS) - A multiscale nonhydrostatic atmospheric simulation and prediction tool, Part I: Model dynamics and verification, Meteor. Atmos. Physics., 75, 161-193, 2000.

Xue, M., Droegemeier, K. K., Wong, V., Shapiro, A., Brewster, K., Carr, F., Weber, D., Liu, Y., and Wang, D.-H.: The Advanced Regional Prediction System (ARPS) - A multiscale nonhydrostatic atmospheric simulation and prediction tool, Part II: Model physics and applications, Meteor. Atmos. Physics., 76, 134-165, 2001.

Xue, M., Wang, D.-H., Gao, J.-D., Brewster, K., and Droegemeier, K. K.: The Advanced Regional Prediction System (ARPS), storm-scale numerical weather prediction and data assimilation, Meteor. Atmos. Physics, 82, 139-170, 2003. 